Kalpa Publications in Civil Engineering
Volume 1, 2017, Pages 307-314
ICRISET2017. International Conference on Re-
search and Innovations in Science, Engineering
\&Technology. Selected papers in Civil Engineering $\quad \mathrm{Kalpor}$

\title{
Shear and Impact Behaviour of Reactive Powder Concrete with Varying Fibre Content
}

\author{
P. B. Patel* \\ Dr. L. S. Thakur ${ }^{*}$ \\ Dr. M. K. Maroliya** \\ B. A. Patel ${ }^{\#}$ \\ Assistant Professor \\ Associate Professor \& \\ Associate Professor \\ Head \\ * Civil Engineering Department, Babaria Institute of Technology, BITS Edu Campus, \\ Vadodara \\ ** Applied Mechanics Department, Faculty of Technology and Engineering, M. S, University, \\ Vadodara \\ \#Design \& Drawing, Ultratech Cement Ltd., Vadodara
}

\begin{abstract}
Reactive powder concrete (RPC) is a novel material due to its high strength and enhanced durability properties. These properties have made it choicest material for external facade cladding thus enabling a considerable reduction in the thickness of concrete elements. The mix design of RPC is such that it affects the heat of hydration in concrete due to its reduced cementitious content. The advantage of this concrete or so to say mortar hinders other properties like permeability, creep and shrinkage. To one limit the material becomes more brittle thereby reducing the possibility of deformation before failure. The present work is an effort to evaluate the shear and impact behavior of RPC due to varying proportions of fibre content in the mix. The results showed marked improvement of strength as well as the crack behavior of the cubes when subjected to shear loading with increase in the load for first cracking.
\end{abstract}

Keywords-Reactive Powder Concrete, Impact, Shear, Steel Fibre

\section{Introduction}

Over the years, concrete has become considerably more complex than the original crushed stone, tile or brick plus sand, lime and water utilized by the Romans. The use of supplementary cementitious materials and additives designed to enhance the properties of concrete has grown significantly throughout the 21 st Century. 'Reactive Powder Concrete' (RPC) is the generic name for a class of cementitious composite materials developed by the technical division of Bouygues, S.A. France in the early 1990s and the world's first RPC structure, the Sherbrooke Bridge in Canada, was constructed in July 1997. RPC has ultra-high durability characteristics resulting from its extremely low porosity, low permeability, limited shrinkage and increased corrosion resistance. The 
characteristics of RPC enable its use in chemically aggressive environment and where physical wear greatly limits the life of other concrete. The presented paper is a detailed investigation which has been carried out by varying the fibre volume fraction in optimized RPC proportion to study their effects on shear and impact strength.

\section{Materials and Mix}

RPC is composed of very fine powders (cement, sand, quartz powder and silica fume), steel fibers (optional) and super plasticizer. The super plasticizer, used at its optimal dosage, decreases the water to cement ratio (W/C) while improving the workability of the concrete. A very dense matrix is achieved by optimizing the granular packing of the dry fine powders. The following granular components are used: Sand, Cement, Quartz sand, Silica fume, whereas steel fibre constitutes a special inclusion. The quartz sand carries advantages of being a very hard material with excellent paste/aggregate interfaces as well as being readily available at low costs. The quartz sand is limited with a maximum particle size of $600 \mu \mathrm{m}$, and the minimum value below $150 \mu \mathrm{m}$ being avoided, in order to prevent interference with the largest cement particles $(80-100 \mu \mathrm{m})$. Fine sand is obtained by screening crushed sand, where the grains are highly angular (Table 1 and Figure 1). The selection of cement cannot be dissociated from that of the super plasticizer. From the point of view of chemical composition, cements with low $\mathrm{C}_{3} \mathrm{~A}$ content give better results, therefore 53 grade OPC of Kamal Brand manufactured by Aditya Birla group has been used for the complete study. Polycarboxylate Ether (PCE) admixtures generally have a greater compatibility, or enhanced performance with a wide range of specialty additives. Super plasticizer has been Procured from BASF Chemicals (India) Pvt. Ltd. with the brand name Glenium-51 (Polycarboxylic ether base) the properties are given in Table 2.

\begin{tabular}{|c|c|}
\hline Sieve Size & \% Passing \\
\hline $1.18 \mathrm{~mm}$ & 100 \\
\hline $600 \mu \mathrm{m}$ & 95.1 \\
\hline $300 \mu \mathrm{m}$ & 38.3 \\
\hline $150 \mu \mathrm{m}$ & 7 \\
\hline $75 \mu \mathrm{m}$ & 0 \\
\hline
\end{tabular}

Table 1: Particle Size Gradation of Sand

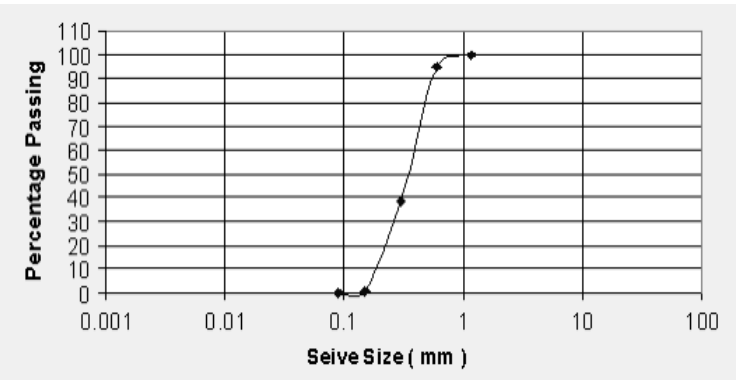

Figure 1: Grading curve of sand used for RPC

\begin{tabular}{|c|c|}
\hline Properties & Specification Limit \\
\hline Specific Gravity & 1.095 \\
\hline Chloride & $\leq 0.10 \%$ \\
\hline $\mathrm{pH}$ & 7.2 \\
\hline Alkali & $\leq 4 \%$ \\
\hline
\end{tabular}

Table 2: Properties of "Glenium-51(Polycarboxylic ether based)" 
Typically the fume/cement ratio used for RPC is 0.27 to 0.3 , which corresponds to optimum filling performance and is close to dosage required for complete consumption of the lime resulting from total hydration of the cement. However, cement hydration is incomplete in an RPC concrete, and the available quantity of silica fume is more than required for the its completion. Silica fume has been procured from Elkem India (P) Ltd. Under the brand name "Elkem Micro silica Grade 920D", the properties are given in Table 3. The Crushed Quartz has been procured from " 20 Microns Ltd." Vadodara with the brand name "Micron Silica 2080" the properties are given in Table 4.

The inherent mix of RPC is brittle in nature so to enhance its ductility, corrugated carbon steel wire micro fibres were added having an overall length of $12.5 \mathrm{~mm}$ with a diameter of $0.45 \mathrm{~mm}$, and a minimum on the wire tensile strength of $2,000 \mathrm{MPa}$. The specific gravity of the steel fibre's material is 7.1. Fibres were procured from Nina Concrete Systems Pvt. Ltd. (Mumbai). Table 5 represents the final optimized mix used for the study giving a comprehensive strength of $150 \mathrm{MPa}$ achieved after a number of trials. The percentage of fibre added varied from 1 to $2.5 \%$ in steps of $0.5 \%$ by weight of cementitious material.

\begin{tabular}{|c|c|}
\hline Properties & Specification Limit \\
\hline $\mathrm{SiO}_{2}$ & $87.3 \%$ \\
\hline Moisture Content & $0.7 \%$ \\
\hline Loss of Ignition $@ 975^{\circ} \mathrm{C}$ & $1.8 \%$ \\
\hline Available Alkalies $\left(\mathrm{Na}_{2} \mathrm{O}\right)$ & $0.5 \%$ \\
\hline Particle Size $>45 \mu$ & $0.7 \%$ \\
\hline Pozzo Activity Index $(7 \mathrm{~d})$ & $182 \%$ \\
\hline Sp. Surface & $20.3 \mathrm{sq} . \mathrm{m} / \mathrm{g}$ \\
\hline Bulk Density & $600 \mathrm{~kg} / \mathrm{cu} . \mathrm{m}$ \\
\hline Density & $2.2 \mathrm{mg} / \mathrm{cu} . \mathrm{m}$ \\
\hline
\end{tabular}

Table 3: Properties of "Elkem Micro silica Grade 920-D"

\begin{tabular}{|c|c|}
\hline Properties & Specification Limit \\
\hline Brightness & $86 \pm 3 \%$ \\
\hline Bulk Density & $450 \pm 50 \mathrm{~g} / \mathrm{lit}$ \\
\hline Oil Absorption & $31 \pm 3 \mathrm{~g} / 100 \mathrm{~g}$ \\
\hline Particle Size Analysis \\
(A) D97 - 97\% particles below & $25 \pm 3 \mu$ \\
(B) D50 - 50\% particles below & $5 \pm 1 \mu$ \\
\hline Moisture (EX - Work) & Max. $0.2 \%$ \\
\hline $\mathrm{pH}(10 \%$ AQ. Slurry) & $9.0 \pm 0.5$ \\
\hline
\end{tabular}

Table 4: Properties of "Micron Silica 2080"

\begin{tabular}{|c|c|}
\hline Material & With fibre* \\
\hline Cement & 1 \\
\hline Silica fume & 0.32 \\
\hline Quartz sand & 0.36 \\
\hline Sand & 1.5 \\
\hline Steel Fibres & 0.2 \\
\hline Water & 0.24 \\
\hline Super-plasticizer & 0.035 \\
\hline
\end{tabular}

Table 5: Optimized RPC mixture (parts by mass)

The weighed quantities of all the dry ingredients are taken and are lightly grind to break-up the agglomerates (if any) in the dry mixture using a planetary type mixture. After adding all the dry ingredients in the mixing mould they were mixed for a while before adding water in to it. The mixing protocol adopted is shown in Table 6. For RPC, flow between $105 \mathrm{~mm}$ to $120 \mathrm{~mm}$ is suitable for achieving good strength. 


\begin{tabular}{|c|c|}
\hline Mixing protocol & $\begin{array}{c}\text { Elapsed } \\
\text { time }\end{array}$ \\
\hline $\begin{array}{c}\text { Lightly grind cement \& silica fume to } \\
\text { break-up agglomerates }\end{array}$ & - \\
\hline Add all dry powders and aggregate & $0 \mathrm{~min}$ \\
\hline Start mixing & $0.5 \mathrm{~min}$ \\
\hline Add 75\% of water & $3 \mathrm{~min}$ \\
\hline Add steel micro-fibres & $5 \mathrm{~min}$ \\
\hline $25 \%$ water and super-plasticizer & $8 \mathrm{~min}$ \\
\hline Stop and cast specimens & $30 \mathrm{~min}$ \\
\hline
\end{tabular}

Table 6: Procedure for mixing of RPC mixes

\subsection{Shear Testing}

The shear testing of samples was carried out on a sample as shown in Figure 2. The setup was a small modification over the JSCE method wherein instead of a rod, a flat plate of size $150 \mathrm{x} 20 \mathrm{x}$ $22 \mathrm{~mm}$ (Figure 2) was used to apply load on a bracket sample.

L-shape moulds of size $150 \times 90 \times 60 \mathrm{~mm}$ are used for the preparation of sample, for shear strength comparison results of which are presented in Table 7 and Figure 3.

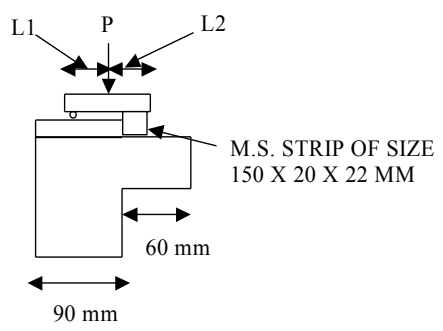

Figure 2: Test Specimen and Loading Arrangement for Shear Testing

\begin{tabular}{|c|c|c|c|c|c|}
\hline $\begin{array}{c}\% \\
\text { Steel } \\
\text { Fibre }\end{array}$ & $\begin{array}{c}\text { Sample } \\
\text { No. }\end{array}$ & $\begin{array}{l}\text { First } \\
\text { Crack } \\
\text { Load } \\
\text { (Ton) }\end{array}$ & $\begin{array}{l}\text { Failure } \\
\text { Load } \\
\text { (Ton) }\end{array}$ & $\begin{array}{c}\text { Shear } \\
\text { Strength }=((\text { Failure } \\
\text { Load in N) } \\
/(2 * 150 * 60)) \\
\left(\mathbf{N} / \mathbf{m m}^{2}\right)\end{array}$ & $\begin{array}{l}\text { Average } \\
\text { Shear } \\
\text { Strength } \\
\left(\mathrm{N} / \mathbf{m m}^{2}\right)\end{array}$ \\
\hline 0 & $\begin{array}{l}1 \\
2 \\
3\end{array}$ & - & $\begin{array}{l}10.50 \\
10.20 \\
11.60\end{array}$ & $\begin{array}{l}5.814 \\
5.648 \\
6.423\end{array}$ & 5.96 \\
\hline 1 & $\begin{array}{l}1 \\
2 \\
3 \\
\end{array}$ & $\begin{array}{c}10.20 \\
9.80 \\
11.10 \\
\end{array}$ & $\begin{array}{l}16.00 \\
13.50 \\
14.50 \\
\end{array}$ & $\begin{array}{l}8.860 \\
7.475 \\
8.029 \\
\end{array}$ & 8.12 \\
\hline 1.5 & $\begin{array}{l}1 \\
2 \\
3\end{array}$ & $\begin{array}{l}12.30 \\
10.10 \\
10.40 \\
\end{array}$ & $\begin{array}{l}19.20 \\
14.60 \\
17.20 \\
\end{array}$ & $\begin{array}{c}10.631 \\
8.084 \\
9.524 \\
\end{array}$ & 9.41 \\
\hline 2 & $\begin{array}{l}1 \\
2 \\
3 \\
\end{array}$ & $\begin{array}{l}11.50 \\
10.89 \\
10.10 \\
\end{array}$ & $\begin{array}{l}21.10 \\
20.00 \\
19.80 \\
\end{array}$ & $\begin{array}{l}11.683 \\
11.074 \\
10.964 \\
\end{array}$ & 11.24 \\
\hline 2.5 & $\begin{array}{l}1 \\
2 \\
3\end{array}$ & $\begin{array}{l}11.20 \\
10.60 \\
11.20\end{array}$ & $\begin{array}{l}17.20 \\
18.90 \\
18.20\end{array}$ & $\begin{array}{c}9.524 \\
10.465 \\
10.078\end{array}$ & 10.02 \\
\hline
\end{tabular}

Table 7: Shear Strength for Varying Steel Fibre Percentage in RPC 
Experimental results illustrate that the ultimate single shear strength for RPC with inclusion of fibres increases considerably over plain RPC. Addition of fibre does not allow the specimen to fail suddenly as well as the failure load show considerable increase. However the addition and quantity of fibre does not significantly affect the first cracking load but a significantly influence on the rate of crack propagation and on the failure load. It can be noted that the improvement in shear strength at first crack and ultimate failure was about $14 \%$ and $88 \%$ respectively with $2 \%$ fibre volume fraction over plain RPC.

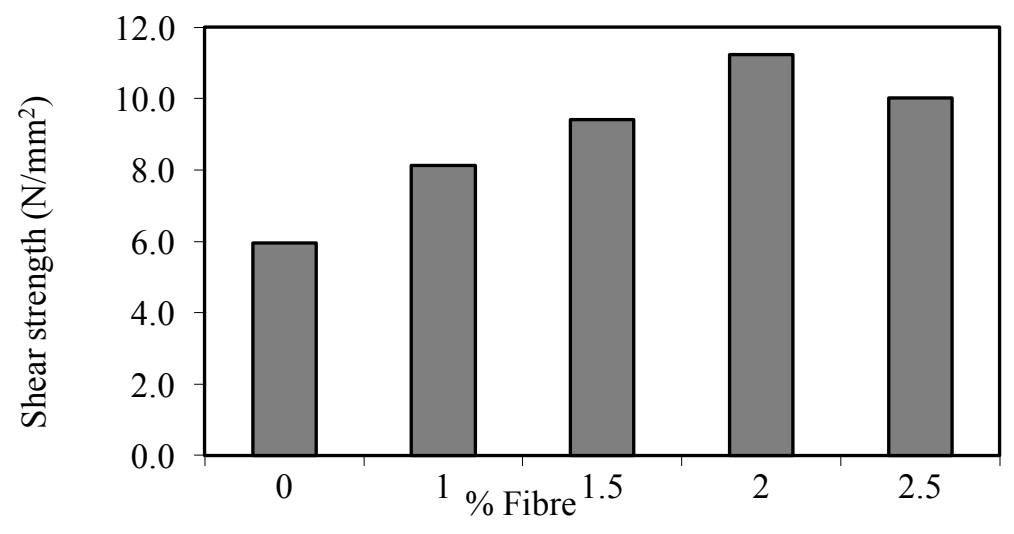

Figure 3: Shear Strength with Varying Fibre Percentage in RPC

\subsection{Impact Testing}

Cylindrical samples with height $64 \mathrm{~mm}$ and diameter $150 \mathrm{~mm}$ were prepared by cutting cylinder of $300 \mathrm{~mm}$ height sliced on a table cutter machine and finished to achieve perfectly horizontal surfaces. The setup shown in Figure 4 was then utilized for testing with a hammer weight of $4.54 \mathrm{~kg}$ dropped through a height of $457 \mathrm{~mm}$ on a steel ball consecutively to cause the first visible crack on the specimen, the number of drops being recorded as impact strength.

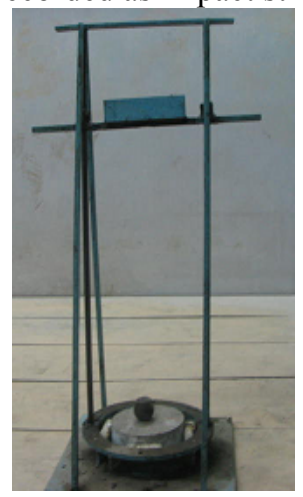

Figure 4: Test Setup for Impact Strength.

The variations in the impact response gained from the different steel fibre variation are tabulated in the Table 8. Plain RPC gives much better resistance to impact as compared to ordinary concrete with the failure being sudden with breakage in two pieces at the end. However addition of the fibre 
did not allow the sample to fail suddenly with only a single crack could be seen at the bottom surface with the sample still being intact as one piece. With further increase in percentage fibre volume fraction, the number of cracks increased in $2 \%$ specimens with the increase in number of blows showing a higher resistance thus showing higher energy absorption. Pulling out of fibres could be seen in these samples (Figure 5). It is also observed that, for $2 \%$ fibre volume fraction specimens, the average number of blows required increased considerably showing a better resistance to impact loading. Percentage increase in impact strength due to addition of fibres in plain RPC is up to $22.34 \%$ while it is 56 times more for $2 \%$ fibre volume fraction compare to M20 Grade concrete.

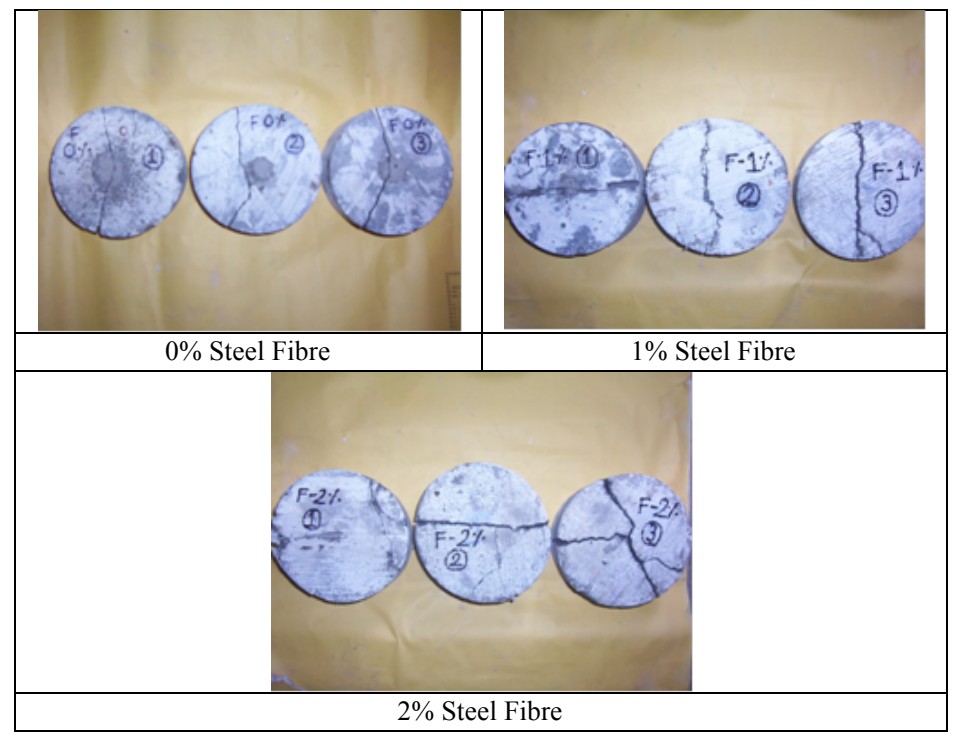

Figure 5: Failed Specimens of Impact Testing

\begin{tabular}{|c|c|c|c|c|c|c|}
\hline $\begin{array}{c}\% \\
\text { Steel } \\
\text { Fibre }\end{array}$ & $\begin{array}{c}\text { Sample } \\
\text { No. }\end{array}$ & $\begin{array}{l}\text { No. of } \\
\text { Blows }\end{array}$ & $\begin{array}{l}\text { Avg. } \\
\text { Blows }\end{array}$ & $\begin{array}{c}\% \\
\text { Increase }\end{array}$ & $\begin{array}{c}\text { Fold } \\
\text { Increase } \\
\text { with } \\
\text { respect to } \\
\text { M20 } \\
\end{array}$ & Remarks \\
\hline \multirow{3}{*}{0} & 1 & 749 & \multirow{3}{*}{783} & \multirow{3}{*}{0} & \multirow{3}{*}{46} & \multirow{3}{*}{$\begin{array}{l}\text { Very Good resistance } \\
\text { seen; Sudden failure } \\
\text { in } 2 \text { parts after } \\
\text { indicated no. of blows }\end{array}$} \\
\hline & 2 & 814 & & & & \\
\hline & 3 & 785 & & & & \\
\hline \multirow{3}{*}{1} & 1 & 802 & \multirow{3}{*}{851} & \multirow{3}{*}{8.68} & \multirow{3}{*}{50} & \multirow{3}{*}{$\begin{array}{l}\text { Not a sudden failure; } \\
\text { a single crack seen } \\
\text { after } \\
\text { indicated number of } \\
\text { blows }\end{array}$} \\
\hline & 2 & 856 & & & & \\
\hline & 3 & 895 & & & & \\
\hline \multirow{3}{*}{2} & 1 & 959 & \multirow{3}{*}{958} & \multirow{3}{*}{22.34} & \multirow{3}{*}{56} & \multirow{3}{*}{$\begin{array}{l}\text { Stretching of fibres } \\
\text { seen; } \\
\text { almost } 3-4 \text { cracks } \\
\text { developed after } \\
\text { indicated no. of } \\
\text { blows }\end{array}$} \\
\hline & 2 & 1002 & & & & \\
\hline & 3 & 912 & & & & \\
\hline
\end{tabular}

Table 8: Impact Strength for Varying Steel Fibre Percentage in RPC 


\section{Conclusions}

$>$ Due to fiber presence, the brittle shear failure of the cubes is not observed. In fact, the cracks get arrested by fibers and multiple cracks are observed.

$>$ It is clear from the experimental work carried out on inverted L-type of samples that the plain RPC samples failed in a brittle manner at the first crack load which is also the maximum load taken by specimen.

$>$ On the other hand, samples having 2.5\% fiber indicated multiple visible cracks however $2 \%$ fiber indicates maximum load taken by the samples quite higher than the first crack load, which clearly reflects failure after the strain hardening of the material.

> In $2.5 \%$ fiber volume fraction inverted L-type of samples multiple cracks were observed but the shear strength was found less than the $2 \%$ fiber samples. Thus, $2 \%$ fibre volume content can be considered as optimum fiber content required for getting desired properties of RPC in shear.

$>$ Under impact loading, the fiber reinforced samples show higher strength and better bonding also, smaller particle size grading improves the impact strength compared to ordinary concrete.

$>$ At 1 and $2 \%$ fibre content the percentage increase in impact strength compare to that of non fibrous sample is found respectively as 8.68 and 22.34 which indicates that for $2 \%$ fibre content RPC specimen has more impact value.

> RPC samples do not disintegrate even under large number of blows in repeated hammer test and absorbs more energy indicating thus higher toughness.

\section{References}

[1] A. S. Dili and Manu Santhanam. "Investigation on reactive powder concrete: a developing ultra high-strength technology". April 2004, Indian Concrete Journal.

[2] Angelika Sicker, "The Influence of Super plasticizer on the Autogenous Shrinkage of High Performance Concrete".

[3] A. Feylessoufi, F. Villieras, L. J. Michot, P. De Donato, J. M. Cases \& P. Richard. "Water environment and nanostructural network in a reactive powder concrete". Cement \& Concrete Composites, Vol.18, 23-29, 1996.

[4] Bruno D’Souza \& Ken Fletcher, "New generation hyper plasticizers for the new millennium”. Degussa Construction Chemicals Australia Pvt. Ltd.

[5] Christian Meyer. "Concrete for the new century". Association of New York City Concrete Producers Spring/Summer 2002.

[6] Charles K. Nmai, David M. Suchorski, AND Patrick L. McDowell, "Aggregates for concrete”. Developed by Committee E-701, Materials for Concrete Construction, ACI Education Bulletin E1-99.

[7] Dong-uk chai, David w. Fowler and James O. Jirsa. "Interface Shear strength of concrete at Early ages" ACI Structural Journal, Vol. 96[3], May-June 1999.

[8] I. G. Barr and K. L. W. Liu. "A Compact shear test specimen” Journal of Materials sciences, UK, Letters 2, 663-664, 1983.

[9] Ji Wen-yu, An Ming-zhe, Yan Gui-ping, and Wang Jun-min. "Study on reactive powder concrete used in sidewalk system of the Qinghai-Tibet railway bridge".

[10] Kazunori Fujikake, Takanori Senga, Nobuhito Ueda, Tomonori Ohno and Makoto Katagiri, "Study on Impact Response of Reactive Powder Concrete Beam and Its Analytical Model” Journal of Advanced Concrete Technology, 4(1) 99-108, 2006

[11] M.Maalej, J.Zhang, S.T.Quek and S.C.Lee "High-Velocity Impact Resistance of Hybrid-Fibre engineered cementitious composites" National University of Singapore, p.p-1051-1058.

[12] Mariano Valle and Oral Buyukozturk. "Behaviour of Fiber reinforced High-strength concrete under Direct Shear" ACI Structural Journal, Vol. 90[2], March-April 1993.

[13] N. Roux, C. Anddrade, and M.A. Sanjuan, "Experimental study of durability of reactive powder concrete", Journal of Materials in Civil Engineering Vol. 8, No. 1, February 1996.

[14] N. P. Lee And D.H. Chisholm, Study report prepared by BRANZ Building and knowledge, on "Reactive powder concrete", No. 1462005.

[15] P. Baruah \& S. Talukdar, "Flexural and shear strength of concrete with Steel, Polyester and Jute Fibers", National Conference on High-Rise Building: Material and Practices. New Delhi, India, October 30-31, 2006.

[16] Parikh Bhaumik, "Study of Recron Fiber Reinforced Engineered Cementatious Composites under Tension, Compression, Shear and Impact", ME Thesis 2007, M.S. University of Baroda. 
[17] Samir A. Ashour, Ghazi S. Hasanain and Faisal F. Wafa. "Shear Behavior of High-strength Fiber reinforced concrete beams" ACI Structural Journal, Vol. 89[2], 176-184, March-April 1992.

[18] Y. S. Tai \& C. C. Tang. "Reactive powder concrete plate response to a flat projectile impact". Department of Civil Engineering, ROC Military Academy, Taiwan, Republic of China.

[19] Yen Lei Voo, Stephen J, Foster and Ian Gilbert. "Shear strength of Fiber Reinforced Reactive Powder Concrete Prestressed Girders without Stirrups", Journal of Advanced Concrete Technology, 4(1) 123-132, 2006. 